\title{
IMPROVING STUDENTS' SPEAKING SKILL THROUGH PROJECT BASED LEARNING (PBL)
}

\author{
Desi Ratna Sari Simbolon ${ }^{1}$, Acep Haryudin ${ }^{2}$, Efransyah $^{3}$ \\ ${ }^{1}$ IKIP SILIWANGI \\ 2 IKIP SILIWANGI \\ ${ }^{3}$ IKIP SILIWANGI \\ 1Desisimbolon354@gmail.com, $\underline{2 \text { haryacep@gmail.com, }}, \underline{3}$ Efransbae@ gmail.com
}

\begin{abstract}
Project Based- Learning (PBL) is one of teaching technique where the students work in group project and it is required students for designing, planning, and carrying out an extended project that produces a publicly- exhibited output such as a product, publication, or presentation. This research used Classrom Action Research as the research method. The sample of this research were 30 students of the tenth grade, Tehnik Instalasi Tenaga Listrik of SMK PGRI 3 CIMAHI. The students assessed by using speaking rubric by Brown 2004. The data were calculated by using SPSS. As the result, the technique can improve the students speaking skill. It is concluded based on data analyzed. In the first cycle, the students categorized as the poor and low English speaking while the second and the third cycle, the students showed a significant achievement and categorized in good average. This technique can be the affective technique that can be used by the teachers who want to improve students' speaking skill.
\end{abstract}

Keywords: Speaking, Students' Difficulties, PBL

\section{INTRODUCTION}

English is an international language. It is used as the unifying language among many languages in this world. That is why English is very important to be mastered especially for those who live in the country where English is not the first or the second language. Just like we are who live in Indonesia, where English as the foreign language means that we do not use English as our mother tongue or we do not use it in our daily life. It is still strange for us. But, even though it is as the foreign language, Indonesian usually learn English for many reasons such as education, business, job career, communication, promotion, and others. It means that English is useful in many aspects. Viewing the importance of English, Indonesia involves English into curriculum.

There are four English skills namely listening, speaking, reading and writing. From all of them, speaking is the most important because it is fulfill peope snips. It is supported by Widdoson (1979; 120-121) in (Babiker, 2018) stated that "speaking initially the most important: people who is familiar with a language are indicated like the native speaker of that language as if speaking included all other kinds of knowing and usually most of the foreign language essentially interested in studying to speak". In addition, (Brown, 2003) said that Speaking is the product of creative construction of linguistic strings, the speaker makes choices of lexicon, structures and discourse. So, speaking considered as the result of studying English or it is the main goal of language learning, it represents all the other aspects of language skills which means that having a good speaking most likely having a good knowledge because through speaking, people can share their ideas, get and produce 
information and the speaker should be able to choose the lexicon, structures and discourse such as the grammatical, the choice of words and topics so that the utterances which are said by the speaker can be understood by the listener.

However, the critical problem that is faced by many students is how to be able to speak English well. There are still many students that cannot speak English even they had studied English since they were in kindergarten till to senior high school. It is around 11 years they had studied English in the school. Studied English for several years still face some difficulties in increasing their English skills especially speaking (Haryudin, 2017). As the data collected by the researcher at SMK PGRI 3 Cimahi in the tenth grade students, of 30 students, mostly, all the them had studied English in the previous years, but when the researcher did a test to assess their base knowledge in speaking, the final result showed that their speaking ability is in the low average. Speaking is still hard to be mastered. (Haryudin \& Jamilah, 2019). As it is said by (Haryudin \& Jamilah, 2019) that Speaking English as a foreign language is perceived as a difficult skill to be taught and learned since the learners have to think and speak at the same time to present their idea orally. He continued that they might also encounter some problems that obstruct them to be good English speaker. The problems that is meant enclosed with lack of self confidence, fear of making mistake, and lack of vocabularies and grammar.

Just like in the reality in the teaching learning process, through the observation in the class, the writer found some problems about the students condition, they are: The students rarely participate in the language class, many students lack of vocabularies, lack of grammar, low motivation to study and even many of them think that English is not useful for the reason that they are too comfort using their mother-tongue namely Indonesian and most frequently speak in Sundanese. When they were asking to speak in English most of them complained, they said that they did not speak English because they were Indonesian and English was not important because it was not used in their daily life. Their knowledge about English are in very low motivation.

Those problems are having no significance differently with the problems activities according to (Ur, 1996) who said that actually there are 4 problems with speaking activities, they are : 1) inhibition, it means that learners are prohibited to speak in foreign language in the classroom, that will arise the students anxiety in speaking such as worried of making mistakes, fearful of criticism or losing face, or simply shy of the attention that their speech attracts. 2) Nothing to say, they do not know what to say because their minds are empty such as they have no reason to express themselves beyond the guilty feeling that they should be speaking. 3) Low or uneven participation means that each one will have only limited talking time. This problem is surrounded by the learners who is good in English to dominate, while others speak very little or even not at all. 4) Mother tongue use, In classes where all, or a number of , the learners share the mother tongue, they may tend to use it: because it is easier, because it feels unnatural to speak with their friends using foreign language, and because they feel less considence if they are speaking their mother tongue. If they are talking in small groups it will be difficult to get some students to be discipline and motivated to keep speaking the target language.

As the researcher observed, all those problems can influence students' willingness to speak English. Actually this is a big problem because the goal of teaching English at senior high school are to reach the functional and informational level of literacy. In functional level, students are able to apply the target language in their daily life such as to communicate, reading newspaper and can understand instruction. In informational level of literacy, students are able to access knowledge with their language ability (BSNP, 2006 in (Zaim, 2017)). In 
addition, students involved to the vocational school in order that when they have graduated from their school, they can directly involved to the worldforce and having good English which will be an additional value for them to be accepted in the good company which use English in their job or career. That is why, English is very important to be mastered.

The goal of many language teachers is to find the right method (Richards 1987:11) in (Nunan, 1992), therefore, the teachers as the students' guiders and the only one mentor in the classroom have to know those problems so that they are able to help the students to solve them. This must be a big assignment for teachers to choose the suitable and the right teaching technique used in the classroom to make the students are motivated, the teaching learning process become effective, valuable and enjoyable for the students. It is supported by (Nunan, 1992), if the right activity are taught in the right way, it can be a lot of fun. For that reason, learners' motivation will raise and the English classroom would become fun and dynamic. Besides, In language classroom, teacher also necessities concentrated in students- centered. Research showed that learners not only respond by digest the information directly, but they also actively implement their knowledge to explore, negotiate, interpret and to create. They study and finding solutions, thus shifting the emphasis toward the process of learning (Barber, 2017).

In sum, all the problems whether they are coming from the students itself or even from the environment, the only one who can change and solve those problems is teacher. However, there are still many teachers don't care of this case, for the reason, teacher too comfort using traditional technique in the classroom where the class is teachers- center. It means that the class are fully controlled by the teacher, some of them are less creativity: they are too lazy to find the new technique, etc. Therefore, this research can be the teacher's instruction or guider to choose the right and the valuable method with the same problem.

Finally as the suitable and valuable method, it is recommended for teacher to use Project Based- Learning (PBL) to solve those entire problems and to achieve the result of the language learning namely having good speaking. According to Patton (2012) Project BasedLearning point to students designing, planning, and carrying out an extended project that produces a publicly- exhibited output such as a product, publication, or presentation. In PBL the students not only study about the language but they also learn how to use that language in their daily life, besides, it leads the students to be critical thinking, become an active learning, and the class will also be fun and dynamic because the students can make project based on their own creativity and usually it will be easier to explain and to present our own creation to other people. It is supported by Vigotsky Lev (1978) in (Rohmahwati, 2016) who stated that Project-based learning is based on the constructivist learning theory, which finds that learning is success and more valuable when the students are active and get involve in implemented their knowledge: Constructivism is a theory based on observation and scientific study about how people learn. People build their own understanding and knowledge of the world, though experiencing things and reflecting on those experiences.

Through PBL students not only know the content of the language but also they will have multiple skills like become an active learning and critical thinking, having good presentation skills, build their self confidence, and all the students will participate in the language classroom because they have the same time talking time and they will also freely to express themselves by presenting their own project and improve their speaking. 


\section{METHOD}

This research was conducted by using classroom action research. The sample of this research was 28 students of the tenth grade students of SMK PGRI 3 CIMAHI in the major of Tehnik Instalasi Tenaga Listrik (TITL). The research was conducted in three cycles. The instruments used by the researcher was observation and test. Test conducted to get the students' scores in pre test and post test while observation to know the students' improvement toward the language learning. Pre- test was attended to know the students' basic knowledge and post-test to know the students' improvement toward teaching technique used by the researcher. The researcher also used speaking rubric by Brown 2004 to assess the students' speaking skill. According to (Brown, 2003) there are 5 aspects to assess the students speaking, they are: Pronunciation, Grammar, Vocabulary, Fluency and Comprehension. The data were calculated by using SPSS.

\section{RESULTS AND DISCUSSION}

\section{Results}

In doing the research, the researcher implemented PBL with Classroom Action Research which consisted of four steps: (1) planning, (2) acting, (3) observation, (4) reflecting. The research was conducted in three cycles. In the first cycle, the researcher made a plan by arranging lesson plan and attended pre-test to assess the students basic knowledge and ability about their English speaking. In this cycle, the researcher also taught the students, when the researcher spoke using English in the class and asked them a question, not many students who gave an answer because they did not understand and confused of what is being asked by the researcher. The students' expression is so different when they listened to the researcher, their attitude showed like it was the first time for them in listening someone speaking English. They were surprised and confused. In this cycle students were very low, they are lack of vocabularies, do not have self confidence to speak, still afraid to make a mistake and English is really strange for them. Their lack of vocabularies make them speak English mixed with Indonesia and the words used dominant Indonesian words. The students were very low in every aspect of speaking such as pronunciation, vocabulary, grammar, fluency and comprehension. The students' individual score just only 30-60 which is gotten from:

Pronunciation : 5 x $4=20$

Grammar : 5 x $4=20$

Vocabulary: 5 x $4=20$

Fluency : 5 x $4=20$

Comprehension: 5 x $4=20$

Total scores $20 \times 5=100$

The rating scores of each aspect are 1-5. To get the final scores, each aspect was multiplied by 4 so the students' total scores of each aspects will be 20 and to get the total score of all the aspects are 20 multiplied by 5 and the result will be 100. After getting the students' score of each aspect, the researcher calculated it using SPSS and the students' mean scores in pre test was 45,5 . Unfortunately this is a very low and poor score so the researcher reflected the problem then improved the teaching technique for the next cycle. In the second cycle, the quantity of students who is given a response more than before, they began to understand what is the teacher talking about, the students still mix the language but in this cycle they use English as dominant. 
Students in the second cycle, still often say "emmmm" "ummmm" and sometimes they need to rephrases sentence because their lack of vocabulary made their comprehension was difficult to understand and occasionally they used inappropriate vocabulary, example when they told about their past activity, sometimes they used infinitive verb. But, it was not as often as before. If it is calculated, the result showed that the students' mean score became 59.00. The students showed the improvement. And in the third cycle, the students became more active in the class, they began to make an effort to give the suitable response to the teacher using English base on the procedure, they more active to speak in every chance they have. Not only in the classroom but also outside of the class the students become usual speak English when they talk with their friends and especially with their English teacher. In this cycle, when the students doing the presentation, their self confidence arised and most of them just made little mistakes. The students' mean scores in the post test were 72.3. Besides, PBL also can make the students have multiple skills like become an active learning and critical thinking, having good presentation skills, build their self confidence, and all the students will participate in the language classroom because they have the same talking time.

\section{Discussion}

Students showed their improvement when they were studying in a group and they became communicate students when they were explained their own project, it was easier for them to explained their own work based on their own creativity. All students became active learning because they were all have the same time to speak, having good self confidence, become an active and critical thinking students. Based on the data, it showed how big the PBL effect toward the students' speaking skill. It proved by the data from 45.5 became 72.3 . it is included that PBL has positive effect toward the students' speaking skill. PBL can improve the students' speaking skill and it can solve all those problems that is mentioned in the background above.

\section{CONCLUSION}

From the data calculated above, it showed that students improvement is very significant before and after they were taught using this technique. It can be seen from the data. From all cycles, the students score always goes up. From the data mentioned above, based on the students' improvement's scores, the researcher concluded that Project Based Learning can improve the students' speaking skill and it is one of an affective teaching technique that may be used by teacher who want to increase their students' speaking skill.

\section{ACKNOWLEDGMENTS}

From the data calculated above, it showed that students improvement is very significant before and after they were taught using this technique. It can be seen from the data. From all cycles, the students score always goes up. From the data mentioned above, based on the students' improvement's scores, the researcher concluded that Project Based Learning can improve the students' speaking skill and it is one of an affective teaching technique that may be used by teacher who want to increase their students' speaking skill.

Without my family, I cannot stand till this time thank you to my Brothers Fransisco Simbolon, Ericson Simbolon, Riky Simbolon, Kevin Manteka, Riko Simbolon and big thanks to my sisters too Lena Nababan, Defi Simbolon, Della Simbolon, Rani Simbolon and Selin Natalia. I hope God bless you all whenever you go and always keep healthy. 
I present my sincere appreciation for my lecturers both Mr. Acep Haryudin, M. Pd and Mr. Efransyah, M. Pd as the researcher's guider, leader and also editor of this research, thank you for always teach and educate the researcher when I was wrong. She also gratefully to principal of SMK PGRI 3 CIMAHI who has let me to conduct the research in the school. Last but not least, thank you for the students $X$ TITL who participate in the class.

\section{REFERENCES}

Babiker, A. (2018). Improving Speaking Skills in EFL Classes through Collaborative Learning. American Scientific Research Journal for Engineering, Technology, and Science (ASRJETS), 44, 137-154.

Barber, L. (2017, June 29). Teaching Methods: Multifacited Projects as Central Strategies for Education. (Gilbert Production Company) Retrieved from https://blog.noplag.com/teaching-methods-multifaceted-projects-as-central-strategiesfor-education/

Brown, D. (2003). Language Assesment: Principles and Classroom Practice. Pearson Education.

Haryudin, A. (2017). THE STUDENTS' ENGLISH SPEAKING COMPETENCE BASED ON KTSP CURRICULUM. ELTIN Journal, Journal of English Language Teaching in Indonesia, 1-12.

Haryudin, A., \& Jamilah, S. A. (2019). TEACHER'S DIFFICULTIES IN TEACHING SPEAKING USING AUDIO VISUAL AID FOR AUTISTIC STUDENTS. ELTIN Journal, Journal of English Language Teaching in Indonesia, 59-70.

Nunan, D. (1992). Research Methods in Language Learning David Nunan. US: Cambridge University Press.

Patton, A. (2012). Work that Matters: The teacher's guide to project based-learning. Paul hamlyn foundation.

Rohmahwati, P. (2016). PROJECT-BASED LEARNING TO RAISE STUDENTS' SPEAKING ABILITY: ITS' EFFECT AND IMPLEMENTATION (A MIX METHOD RESEARCH IN SPEAKING II SUBJECT AT STAIN PONOROGO). Kodifikasia. https://doi.org/10.21154/kodifikasia.v9i1.466

Ur, P. (1996). A Course in Language Teaching: Practice of Theory. Cambridge University Press.

Zaim, M. (2017). Implementing Scientific Approach to Teach English at Senior High School in Indonesia. Asian Social Science, 13. https://doi.org/10.5539/ass.v13n2p33 